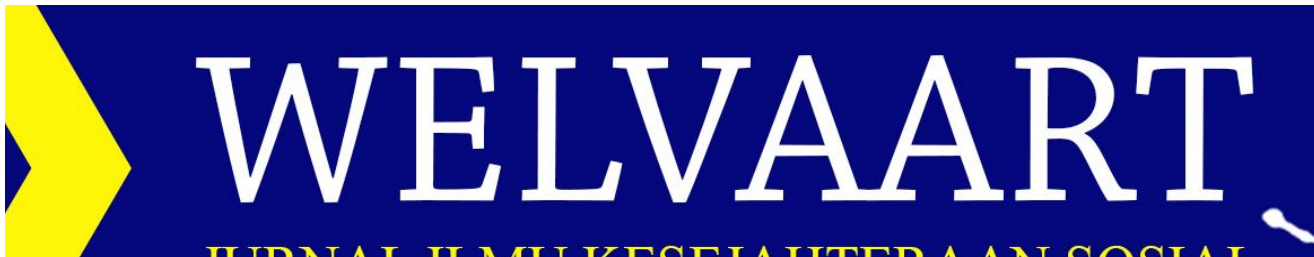

JURNAL ILMU KESEJAHTERAAN SOSIAL

\title{
DAMPAK MEROKOK TEHADAP KONDISI KESEJAHTERAAN KELUARGA \\ (Studi di Kelurahan Lakorua Kecamatan Mawasangka Tengah Kabupaten Buton Tengah)
}

\author{
Desi Andrini Rosminah1, Jamaluddin Hos2, Sarpin3 \\ Universitas Halu Oleo
}

\begin{abstract}
ABSTRAK
Penelitian ini dilaksanankan di Kelurahan Lakorua Kecamatan Mawasangka Tengah Kabupaten Buton Tengah. Adapun masalah dalam penelitian ini adalah Bagaimana Dampak merokok tehadap kondisi kesejahteraan keluarga di Kelurahan Lakorua Kecamatan Mawasangka Tengah Kabupaten Buton Tengah? Dan Bagaimana Upaya Pemerintah Setempat untuk mengatasi Dampak merokok tehadap kondisi kesejahteraan keluarga di Kelurahan Lakorua Kecamatan Mawasangka Tengah Kabupaten Buton Tengah? Tujuan penelitian ini adalah untuk mengetahui Dampak merokok tehadap kondisi kesejahteraan keluarga di Kelurahan Lakorua Kecamatan Mawasangka Tengah Kabupaten Buton Tengah Dan untuk mengetahui Upaya Pemerintah Setempat untuk mengatasi Dampak merokok tehadap kondisi kesejahteraan keluarga di Kelurahan Lakorua Kecamatan Mawasangka Tengah Kabupaten Buton Tengah.Informan dalam penelitian ini dipilih secara sengaja yang berjumlah 14 orang dan terdiri dari perokok 9 orang dan mantan perokok 2 orang. ditambah dengan 3 orang informan kunci yakni Lurah Lakorua, Tokoh Pemuda Kelurahan Lakorua serta Dokter Umum di Puskesmas Kecamatan Mawasangka Tengah. Hasil penelitian menunjukan bahwa dampak merokok terhadap kondisi kesejahteraan keluarga, yaitu : (a.) Pengeluaran, (b.) Perumahan (c.) Pangan (d.) Sandang (e.) Pendidikan (f.) Kesehatan. (g.) Tabungan. Adapun Upaya pemerintah setempat untuk mangatasi dampak merokok, yakni Upaya yang dilakukan bekerjasama dengan pihak puskesmas untuk mensosialisasikan dampak merokok dalam kehidupan sehari-hari.
\end{abstract}

Kata Kunci: Dampak Merokok, Kesejahteraan Keluarga, Kesehatan Keluarga.

\section{PENDAHULUAN}

Indonesia merupakan salah satu negara dengan industri rokok terbesar di dunia. Industri rokok di Indonesia merupakan salah satu penyumbang devisa terbesar negara. Karena industri rokok dipandang mampu memberikan lapangan kerja bagi ribuan orang. Selain itu industri rokok juga mampu mengembangkan pertanian dengan penanaman tembakau sebagai bahan baku utama rokok dan dengan meningkatnya produksi tembakau maka akan meningkatkan kesejahteraan petani dan menyerap tenaga kerja untuk menanam tembakau. Keberadaan industri rokok di Indonesia memang dilematis, karena dibalik semua keuntungan ekonomis itu rokokjuga membawa dampak buruk bagi kehidupan manusia antara lain meningkatkan polusi udara, menimbulkan berbagai macam penyakit, serta menimbulkan berbagai kerawanan sosial yang terjadi dalam masyarakat.

Pemerintah Indonesia pada tanggal 24 Desember 2012 lalu resmi menandatangani peraturan pemerintah (PP) nomor 109 tentang pengamanan bahan yang mengandung zat adiktif berupa produk tembakau bagi kesehatan. Secara umum penerbitan PP 
dinilai lebih banyak mengatur bisnis rokok dan tembakau dari pada mengatur kesehatan. Ada pengaturan iklan, promosi, sponsor, tar dan nikotin, diversifikasi tembakau, penjualan rokok dan lainnya. Menurut Arist Merdeka Sirait (Ketua Komnas PA), beberapa substansi lain dari PP No. 109 Tahun 2012 tersebut masih harus dikritisi, antara lain, mengenai penegasan peraturan seperti larangan menyuruh anak di bawah 18 tahun untuk menjual, membeli, atau mengkonsumsi rokok. Kegiatan yang disponsori roko dilarang melibatkan anak di bawah 18 tahun. (http://health.kompas.com/).

Rokok sangat membahayakan kesehatan. Bukan hanya membahayakan para perokok, asap rokok juga sangat berbahaya apabila dihirup oleh orang-orang yang berada disekitarnya atau biasa disebut perokok pasif. Berbagai kandungan zat yang terdapat di dalam rokok memberikan dampak negatif bagi tubuh penghisapnya. Bahkan sebagian penelitian menunjukkan bahwa para perokok pasif memiliki resiko kesehatan yang lebih tinggi dari pada para perokok itu sendiri.

Rokok merupakan salah satu zat adiktif yang di dalamnya terdapat nikotin yang bersifat adiktif dan tar yang bersifat karsinogenik yang dapat mengakibatkan berbagai penyakit. Kandungan zat yang ada di dalam rokok dapat menjadi pintu masuk ke narkotika dan obat-obatan terlarang lainnya. Merokok berkaitan erat dengan disabilitas dan penurunan kualitas hidup. (http://repository.unib.ac .id/9167/2/I,II,III,I-14mar-FS.Pdf.)

Penelitian ini bersifat melengkapi penelitian sebelumnya yang fokus membahas dampak merokok terhadap kondisi kesejahteraan keluarga di Kelurahan Lakorua Kecamatan Mawasangka Tengah Kabupaten Buton Tengah. Kelurahan Lakorua memiliki jumlah penduduk 1.501 jiwa dan $364 \mathrm{KK}$ jumlah ini sebagian besar mereka adalah perokok.

Di Kelurahan Lakorua dengan jumlah perokok aktif sebanyak 268 orang atau $73,62 \%$ sedangakan perokok pasif dengan jumlah 96 orang atau 26,38\%. Alasan utama masyarakat Kelurahan Lakorua menjadi perokok diawali dengan pertama yaitu ikut-ikutan dan yang kedua ingin mencoba-coba. Masyarakat Kelurahan Lakorua sebagian besar bekerja sebagai petani dan penjual sembako dengan mengharapkan hasil kebun dan laba dari sembako tersebut sebagai sumber pendapatan keluarga. Selain itu kelompokkelompok kerja tidak produktif oleh karena keterbatasan modal dan kualitas kerja sehingga hasil yang di peroleh kepala keluarga belum dapat meningkatkan kesejahteraan anggota keluarganya. Olehnya itu, berangkat dari fenomena latar belakang diatas dan berdasarkan hasil penelitan sebelumnya maka penulis tertarik mengadakan penelitian dengan judul "Dampak Merokok Terhadap Kondisi Kesejahteraan Keluarga (Studi Di Kelurahan Lakorua Kecamatan Mawasangka Tengah Kabupaten Buton Tengah)".

Adapun yang menjadi rumusan masalah dalam penelitian ini adalah Bagaimanakah dampak merokok terhadap kondisi kesejahteraan keluarga di Kelurahan Lakorua Kecamatan Mawasangka Tengah Kabupaten Buton Tengah dan Bagaimanakah upaya pemerintah setempat untuk mengatasi dampak merokok terhadap kondisi kesejahteraan keluarga di Kelurahan Lakorua Kecamatan Mawasangka Tengah Kabupaten Buton Tengah. Sedangkan yang menjadi tujuan dari penelitian ini adalah Untuk mengetahui dampak merokok terhadap kondisi kesejahteraan keluarga di Kelurahan Lakorua Kecamatan Mawasangka Tengah Kabupaten Buton Tengah dan Untuk mengetahui upaya pemerintah setempat dalam mengurangi dampak merokok terhadap kondisi kesejahteraan keluarga di Kelurahan Lakorua Kecamatan Mawasangka Tengah Kabupaten Buton Tengah. 


\section{METODE PENELITIAN}

Metode penelitian yang digunakan dalam penelitian ini adalah kualitatif dan untuk penentuan informannya peneliti menggunakan teknik purposive sampling, dengan pertimbangan bahwa informan tersebut mampu menjawab permasalahan dalam penelitian ini yakni terkait dengan dampak merokok dan upaya untuk mengatasi dampak merokok, informan tersebut berjumlah 14 (empat belas orang) yaitu 3 orang informan kunci (key informan) yakni Lurah Lakorua, Dokter Umum Puskesmas Mawasangka Tengah dan Tokoh Pemuda Kelurahan Lakorua, informan Perokok 9 orang dan informan Mantan Perokok 2 orang. Setelah seluruh informasi dikumpulkan, baik melalui proses observasi, wawancara maupun dokumentasi maka selanjutnya peneliti melakukan analisis data dengan mengunakan deskriptif kualitatif. Adapun proses analisis data yang dilakukan mengikuti pola sebagaimana yang disistematikan oleh Miles dan Huberman (dalam Satori dan A'an, 2010 : 39) yang mengemukakan bahwa analisis data yaitu menggambarkan secara sistematis dan mendalam setiap masalah yang ditelaah. Analisa yang berlangsung melalui empat tahap yakni : pertama, data collection (tahap pengumpulan data) yaitu pada saat proses memasuki lingkungan penelitian dan melakukan pengumpulan data penelitian. Kedua, data reduction (tahap reduksi data) yaitu pada saat proses pemilihan data, pemusatan perhatian pada penyederhanaan, pengabstrakan dan transformasi data kasar yang muncul dari catatan-catatan tertulis dari lapangan. Ketiga, data display (tahap penyajian data) yakni penyajian informasi dalam memberikan kemungkinan adanya penarikan kesimpulan dan pengambilan tindakan. Keempat, tahap penarikan kesimpulan, pada tahap ini penarikan kesimpulan dari data yang telah dianalisis, sehingga akan diharapkan penelitian benar-benar menggambarkan kenyataan.

\section{PEMBAHASAN}

\section{a. Dampak Merokok Terhadap Kondisi Kesejahteraan Keluarga di Kelurahan Lakorua Kecamatan Mawasangka Tengah Kabupaten Buton Tengah.}

Penelitian yang dilakukan di kelurahan Lakorua kecamatan mawasangka tengah adalah untuk mengetahui Dampak Merokok Terhadap Kondisi Kesejahteraan Keluarga. Berbicara tentang dampak berarti berbicara tentang akibat dari adanya suatu kejadian yang terjadi pada masyarakat baik karena suatu kejadian itu mempengaruhi masyarakat atau hal lain yang ada dalam masyarakat. Dampak berarti benturan, pengaruh kuat yang mendatangkan akibat baik positif maupun negatif. Menurut Samodra Wibawa (dalam Hamsari 2009 : 7) mengatakan bahwa ampak adalah akibat yang dihasilkan oleh suatu intervensi program pada kelompok sasaran baik akibat tersebut sesuai dangan apa yang diharapkan oleh suatu intervensi program maupun tidak ada akibat tersebut maupun menimbulkan pola perilaku baru pada kelompok sasaran.

1. Pengeluaran Rumah Tangga

Pengeluaran adalah uang yang dikeluarkan untuk kebutuhan hidup yang kecil maupun besar. contohnya: pengeluaran untuk kebutuhan hidup keluarga pada umumnya baik jangka pendek, jangka meneggah, jangka panjang dan Kelurahan Lakorua pada khususnya di kelurahan ini juga akan memberikan dampak yang sangat besar baik itu positif maupun negatif dalam aspek ini bisa dilihat dari tingkat kesejahteraan keluarga dan masyarahat pada umumnya baik itu pengeluaran, 




manusia melalui upayah pengajaran dan pelatiahan dengan metode-metode tertentu sehingga orang memperoleh pengetahuan dengan tujuan meningkatkan sumber daya manusia baik sebagai individu maupun manusia sebagai kelompok sosial. Termasuk di Kelurahan Lakorua pendidikan adalah kebutuhan pokok manusia hubungannya dengan penelitan ini yakni dampak merokok terhadap kondisi kesejahteraan keluarga. Pendidikan merupakan suatu proses pemberdayaan peserta didik sebagai objek dalam membangun kehidupan yang baik. Mengingat pendidikan sangat berperan dalam meningkatkan kualitans sumber daya manusia, maka pembangunan dibidang pendidikan meliputi pendidikan secara formal maupn non formal. Untuk mencapai sasaran tersebut, berbagai upaya telah dilakukan pemerintah dengan meningkatkan sarana dan prasarana pendidikan, perbaikan kurikulum dengan harapan tingkat pendidikan semakian membaik dan tentunya akan berpengaruh pada tingkat kesejahteraan keluarga.

6. Kesehatan

Pengertian kesehatan menurut Organisasi Kesehatan Dunia (WHO), (dalam Armadin: 2016), menyebutkan bahwa pengertian kesehatan adalah sebagai suatu keadaan fisik, mental, dan sosial kesejahteraan dan bukan hanya keadaan penyakit atau kelemahan. Secara umum kesehatan adalah keadaan sejahterah dari badan, jiwa, dan sosial yang memungkinkan setiap orang hidup produktif secara sosial dan ekonomis. Upaya kesehatan adalah setiap kegiatan untuk memelihara dan meningkatkan kesehatan yang dilakukan oleh pemerintah, masyarakat dan kesehatan. Termasuk di Kelurahan Lakorua kesehatan adalah kebutuhan pokok semua manusia hubungannya dengan penelitan ini yakni dampak merokok terhadap kondisi kesejahteraan keluarga. Jika keluarga dan masyarakat pada umumnya merokok terus menerus pasti akan memberikan dampak terhadap kebutuhannya aspek ini fokus membahas kesehatan.

7. Tabungan

Secara umun dan sederhana, tabungan adalah sebagian pendapatan yang tidak dihabiskan atau tidak digunakan. Tabungan juga bisa diartikan sebagai sebuah cara yang dilakukan untuk berhemat demi mendapatkan simpanan yang bisa digunakan sewaktu-waktu saat dibutuhkan.

b. Upaya Pemerintah Setempat Untuk Mengatasi Dampak Merokok Terhadap Kondisi Kesejahteraan Keluarga di Kelurahan Lakorua Kecamatan Mawasangka Tengah Kabupaten Buton Tengah.

Zaman sekarang banyak masyarakat Indonesia mengkonsumsi rokok hampir sebagai kebutuhan pokok mereka. Hal ini menjadi penyumbang bagi angka kematian sebesar $22,5 \%$ (akibat rokok) dari total kematian pertahunnya di Indonesia. Keadaan ini tentunya tidak boleh serta tidak dapat dibiarkan berlanjut secara terus menerus. Diperlukan upaya-upaya pintar untuk mencegah masyarakat merokok dan juga mengatasi para perokok.

(http://www.godsdirectcontact.or.id/kesehatan/Rokok.htm)

Melihat dampak negatif dari zat berbahaya yang di akibatkan oleh perokok pasif maka mulailah untuk waspada dan mencari cara mencegahnya. Bagaimana cara mencegah perokok pasif dengan menghindari asap rokok. (http://cegahsakit.com/179/ bahaya-perokok-pasif-dan-cara-mencegahnya). Mengingatkan atau memberi saran. Pengertian mengingantkan atau memberi saran adalah sebuah solusi yang di tunjukkan untuk menyelesaikan permasalahan yang di hadapi. Saran ini harus bersifat membangun, mendidik, dan secara objektif 


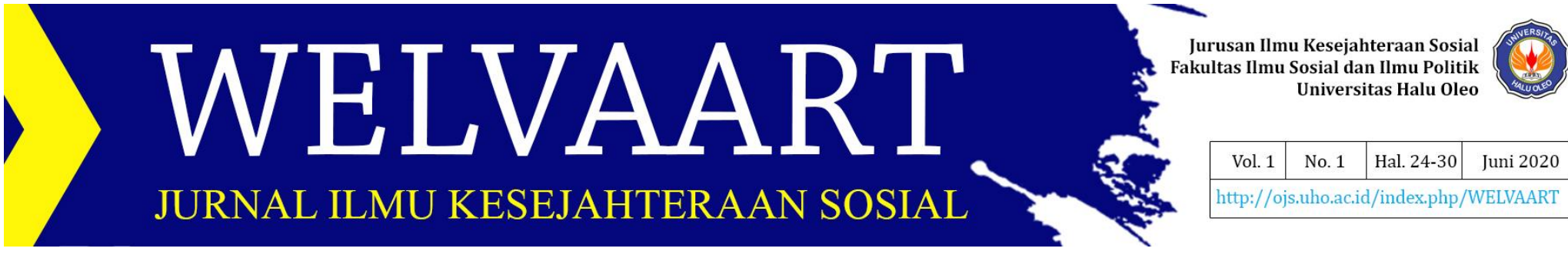

dan sesuai dengan topik yang di bahas. Berilah saran kepada perokok untuk sekedar mengingatkan tentang dampak dari asap rokok bagi perokok pasif, berikan saran secara bijak dengan bahasa yang mudah dipahami. (http://brainly.co.id-B. Indonesia). Termasuk di Kelurahan Lakorua tentunya mempunyai upaya untuk mengatasi Dampak Merokok Terhadap Kondisi Kesejahteraan Keluarga upaya ini bukan hanya pemerintah kelurahan yang laksanakan namun bekerjasama dengan pihak Puskesmas setempat. Karena Puskesmas sendiri mempunyai Program Kerja salah satunya adalah upaya atau mensosialisasikan dampak merokok dan biasa mereka lakukan tiap satu kali dalam setahun tetapi pihak Puskesmas juga selalu menyisipkan materi-materi akan dampak merokok disetiap sosialisasi-sosialisasi yang lainnya.

\section{PENUTUP}

a. Kesimpulan

1. Dampak Merokok Terhadap Kondisi Kesejahteraan Keluarga di Kelurahan Lakorua Kecamatan Mawasangka Tengah Kabupaten Buton Tengah.

Pengeluaran yaitu, aspek ini sangat besar dampaknya terhadap keluarga di Kelurahan Lakorua terlihat saat mereka belanja kebutuhannya sehari hari khususnya membeli rokok bagi mereka pengguna rokok dengan pengeluaran meraka yang cukup banyak menjadikan rumah tangga perokok di Kelurahan Lakorua ini semakin meingkat. Perumahan, jika uang yang digunakan untuk kebutuhan rumah atau perawatan rumah maka sangat memberikan manfaat terutama untuk kesejahteraan keluarga. Pangan (Makanan) yaitu, bila uang yang mereka gunakan untuk membeli rokok dialihkan untuk membeli makanan dalam hal ini beras, ikan, sayur dan yang lainnya pasti akan memberikan manfaat dan akan meningkatkan kesejahteraan keluarga di Kelurahan Lakorua. Sandang (Pakaian) yaitu, kalau untuk merokok mereka tidak bisa tinggalkan karena mereka sudah anggap sebagai kebutuhan pokok juga dan biasanya uang yang mereka gunakan untuk beli pakaian anak dan istri harus mereka tunda demi untuk membeli rokok dan mereka anggap juga pakaian itu masuk dalam kebutuhan tambahan karena bagi mereka rokoklah yang menjadi kebutuhan pokok. Pendidikan yaitu, dampaknya terhadap keluarga di Kelurahan Lakorua karna mereka ini awalnya tidak suka yang namanya merokok, waktu mereka masih duduk di bangku SMP sampai SMA hingga mereka lulus hampir semua para perokok. Jadi mereka merokok itu karna faktor coba-coba, kemudian ajakan dari teman-teman sekelas dan di sekolah lain juga di ajak untuk merokok tapi merokoknya sembunyi-sembunyi dan diluar jam sekolah. Kesehatan yaitu, aspek ini sangat besar dampaknya terhadap keluargat di Kelurahan Lakorua sebab kebanyakan yang merekok itu adalah kepala keluarga itu sendiri, mereka tidak perduli akan penyakit yang di sebabkan oleh rokok. Tabungan yaitu, jika uang yang mereka keluarkan untuk membeli rokok mereka tabung, pasti kebutuan mereka semua akan terpenuhi.

2. Upaya Pemerintah Untuk Mengatasi Dampak Merokok TerhadapKondisi Kesejahteraan Keluarga di Kelurahan Lakorua Kecamatan Mawasangka Tengah Kabupaten Buton Tengah adalah sebagai berikut. Upaya yang dilakukan yakni bekerjasama dengan pihak puskesmas untuk 


\section{WELVAART}

JURNAL ILMU KESEJAHTERAAN SOSIAL

mensosialisasikan dampak merokok dalam kehidupan sehari-hari mengingat banyaknya jumlah perokok di kelurahan ini tentunya akan banyak pula yang akan terkena dampaknya usaha ini dilakukan dengan harapan agar jumlah perokok di kelurahan lakorua bisa berkurang.

b. Saran

1. Untuk Lurah Lakorua dan pemerintah setempat, serta pihak Puskesmas Kecamatan Mawasangka Tengah diharapkan dapat memperhatikan masyarakat Kelurahan Lakorua yang mayoritas perokok dengan cara terus menerus melakukan peyuluhan maupun sosialisasi untuk memberikan kesadaran akan dampak yang akan diakibatkan oleh rokok.

2. Untuk masyarakat yang merokok maupun yang sudah berhenti merokok, maupun semua pihak yang peduli akan dampak rokok, diharapkan dapat bisa berhenti secara permanen untuk tidak merokok lagi dan bisa menyadarkan teman, sahabat maupun semua masyarakat Kelurahan Lakorua akan dampak yang akan diakibatkan oleh rokok.

\section{DAFTAR PUSTAKA}

Armadin, Muhammad, 2016. Dampak Program Nasional Pemberdayaan Masyarakat (PNPM) Mandiri Terhadap Kondisi Sosial Ekonomi Masyarakat Studi Kelurahan Lakorua Kecamatan Mawasangka Tengah Kabupaten Buton Tengah. Skripsi, Kendari : Universitas Halu Oleo

Badudu, Zain. 2007. Kamus Umum Bahasa Indonesia. Pustaka Sinar Harapan, Jakarta.

Badan Pusat Statistik. 2003. Indikator Kesejahteraan Sosial. BPS Sultra. Kendari. Hamsari, 2009. Dampak Budaya Asing Terhadap Motivasi Kerja Karyawan PT Wakatobi Divers Resort, Skripsi Sarjana Unhalu. Kendari.

Satori, Djam'an dan Komariah A'an. 2010. Metode Penelitian Kualitatif. Alfabeta. Bandung.

Syam. Noor M. 1980. Pengantar Dasar-dasar Pendidikan. Usaha Nasional. Surabaya.

http://health.kompas.com/

http://cegahsakit.com/179/bahaya-perokok-pasif-dan-cara-mencegahnya

http://www.godsdirectcontact.or.id/kesehatan/Rokok.htm

http://repository.unib.ac.id/9167/2/I,II,III,I-14-mar-FS.Pdf.

http://repository.usu.ac.id/Bitstream.Pdf.

http://brainly.co.id-B. indonesia 